\title{
EFFECTS OF THE MENHADEN AND MACKEREL FISHERIES UPON THE FISH SUPPLY * * *
}

From BULLE'TIN OF THE BUREAU OF FISHERIES, Volume XXVIII, IgO8

Proceedings of the Fourth International Fishery Congress : : Washington, I008

-

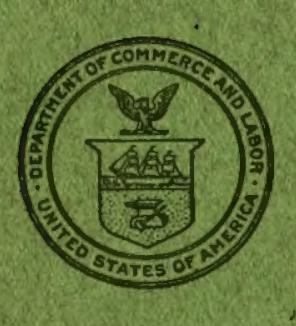

WASHINGTON : : : : : : GOVERNMENT PRINTING OFFICE : : : : : : 1910 


$$
\gamma
$$






\section{EFFECTS OF THE MENHADEN AND MACKEREL FISHERIES UPON THE FISH SUPPLY * * $*$}

From BULLETIN OF THE BUREAU OF FISHERIES, Volume XXVIII, IgO8

Proceedings of the Fourth International Fishery Congress : : Washington, roo8

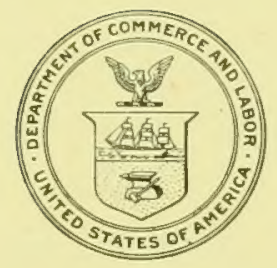

WASHINGTON : : : : : : GOVERNMENT PRINTING OFFICE $: \quad: \quad: \quad: \quad: \quad 1910$ 


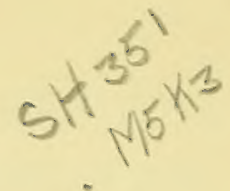

BUREAU OF FISHERIES DOCUMENT NO. 658

Issued February, 1910

MAR 21910

D. 유 8 


\title{
EFFECTS OF THE MENHADEN AND MACKEREL FISHERIES
} UPON THE FISH SUPPLY

\author{
$*$ \\ By W. C. Kendall \\ Assistant, U. S. Burean of Fisheries

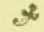

Paper presented before the Fourth International Fishery Congress

held at Washington, U. S. A., September 22 to 26, 1908 


\section{CONTENTS.}

4

Schooling of fishes....

Inadequacy of available information $\ldots \ldots \ldots 2$

Habitat and movements of menhaden and mackerel $\ldots \ldots \ldots \ldots$

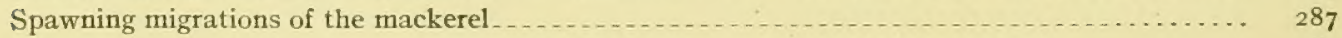

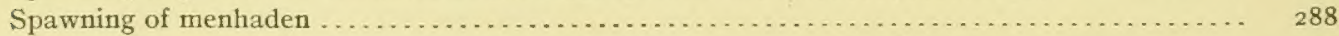

Relation of menhaden to fishes that feed upon them $\ldots \ldots \ldots \ldots \ldots \ldots \ldots \ldots \ldots \ldots \ldots \ldots . .290$

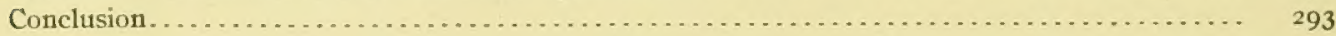

280 


\title{
EFFECTS OF THE MENHADEN AND MACKEREL FISHERIES UPON THE FISH SUPPLY.
}

\author{
$*$ \\ By W. C. KENDALL, \\ Assistant, United States Bureau of Fisheries.
}

$*$

SCHOOLING OF FISHES.

There are various degrees of gregariousness among fishes. Probably there are but few fishes that do not swim in schools at some stage of their existence, and there are few, if any, that are always in schools. The very young of most species, as a rule, occur in schools of greater or less extent. The broods of fishes from ova laid in more or less stationary collections or floating agglutinated masses naturally occur in family groups of brothers and sisters. Floating eggs, while sometimes scattered, are perhaps oftener assembled through the effects of winds, minor currents, etc. The young from such eggs to some extent constitute brotherly and sisterly aggregations, though probably they are more frequently mixed broods. Some species commonly regarded as nongregarious are occasionally observed in schools in their young or adult stages.

The schooling habit is so common among fishes that it must in some way be an advantage to them, although it not infrequently is an obvious and decided disadvantage. The most pronounced types of gregarious fishes are comprised in the scombroid and clupeoid groups, but among the species of these groups there is considerable diversity in respect to the habit. The most representative and perhaps the most perfect examples of the schooling fishes of these two great groups are, respectively, the common mackerel and menhaden.

The eggs of the mackerel float. They are supposedly deposited at the bottom, whence they rise to the surface and are subject to the influences of winds, waves, and currents, which factors determine whether they shall be scattered or aggregated.

Practically nothing is known of the place of spawning of the menhaden or the character of its eggs - whether agglutinated, attached to objects, or free, or whether they sink or float. But the fact remains that as soon as the young of either the mackerel or the menhaden are observed they are in schools. The very young of either species have not been observed except in the case of arti- 
ficially hatched mackerel. When naturally hatched mackerel are first observed they are at least 3 or 4 inches long, and menhaden have never been seen under I inch in length.

Eggs that are stationary or agglutinated, if they are from a single parent and all subject to the same conditions, will hatch at approximately the same time and produce fish of comparatively uniform size. Aggregations of floating eggs are likely to be derived from several parents, laid at somewhat different times, and consequently will produce young of somewhat more diverse sizes. In both instances the rate of growth of individuals varies, causing a difference in size, but on the whole each school of young fish is composed of individuals of fairly uniform sizes. This uniformity appears to be to a great extent permanently maintained; yet it not infrequently happens that schools of two or more sizes become mixed, especially when a school is first broken up by any means and the scattered fish subsequently join other schools.

Whether the schooling habit of the early stage is retained and is the basis of the schools of larger sizes up to adults is impossible to say. That such is the case is indicated by the comparative uniformity in size of individuals of schools of larger fish. Sometimes, however, a school is so large that it could hardly be the original brood or aggregation only, but several, or perhaps many, broods. But such a "raft" is composed of individuals of comparatively uniform sizes, or of sizes suggesting that the fish are of about the same age.

The occurrence of such extensive "rafts" or "bodies " of uniformly sized fish in the spring of the year suggests that possibly the younger fish have a somewhat different habitat from the older ones at that season of the year when they are beyond observation-that is, after they have "left the coast" and prior to their "return." But, as mentioned in the case of young fish, accidentally mixed schools of older fish of the same species, as well as schools containing unrelated species, are not uncommon. Mixed schools of large and smaller fish, or schools containing adventitious species, are likely to occur when the schools have been broken up and driven about by predaceous animals or by purseseiners. Such broken-up schools or straggling individuals, or even small schools, are prone to fall into the procession when a larger body of fish happens along, even though it is of a widely different species, if it is not inimical. Another possible cause of mingling is when the fish are feeding upon the same kind of food and the food happens for any reason to be bunched.

\section{INADEQUACY OF AVAILABLE INFORMATION.}

Since the History of the American Menhaden, in 1877, and a brief summary of that work in I884, also by G. Brown Goode, there has been little published regarding the habits of this fish. This history is remarkably comprehensive, there being hardly a point regarding the menhaden that is not treated more or less exhaustively. The work was, however, an enlargement of manu- 
script notes furnished by Professor Baird, based upon opinions and information clicited by means of circulars from fishermen, manufacturers, customs officers, light keepers, etc., supplemented to some extent by observations by United States fisheries agents. Doctor Goode states that it was found necessary to make allowances for many inaceuracies of statement on the part of his correspondents, and that some of them, having been unable to gbtain exact information, had ventured to guess at what they did not really know from experience. It might possibly liave been added that some of that which they "really dicl know from experience" may have been inaccurate from misinterpretation of phenomena or errors of observation. Doctor Goode admits also that there remains much to be learned, but presents his views regarding the most plausible theories, which must, until more thorough and systematic investigations are made, take the place of actual knowledge. These theories have taken the place of actual knowledge, so far as publication is concerned, to the present day, for since Goode's History there is no adequate account of the menhaden accessible to the student or the public.

During the early nineties the United States Bureau of Fisheries made the menhaden and mackerel subjects of special investigation, and a vast amount of data was accumulated, though never utilized, at least in publication. The present writer was engaged in both investigations during those years and has since from time to time had opportunities, of which he has availed himself, to observe both species under various conditions and in various places. It is upon the personal observations thus made, together with some of the unpublished notes in the files of the Bureau of Fisheries, that this essay is based. Owing to present limits of space, howerer, the writer is compelled to leave his statements mainly unsupported by any transeription of the copious notes mentioned, and also must assume that the andience is familiar with the published literature upon the species herein treated.

\section{HABITAT AND MOVEMENIS OF MENHADEN AND MACKEREL.}

That the labits of some fishes of different ages differ to some extent in regard. to their food, and consequently their habitat, is well known. It is a matter of common observation to those who have given attention to the habits of the menhaden that the different sizes, as a rule, are found in different places and under different conditions. The smaller the fish, the shallower the water and the farther up creeks and streams it occurs, even in fresh water. This may be for either or both of two reasons: (I) Owing to different character of food of the different sizes, or (2) for protection against enemies. Perhaps the latter is the more probable.

Young mackerel 4 to 5 inches long occur sometimes abundantly well up harbors, even about the docks, where larger mackerel never appear. They have been plentiful in Gloucester and Portland harbors, in the former place sometimes 
close to shore in shallow water. As suggested before, in the case of menhaden, they may enter these places for food or for protection, but as they subsist to a great cxtent upon minute crustaceans which abound outside they could hardly be there solely for the sake of food.

During the period when they are beyond observation it is, of course, not known to what extent menhaden and mackerel feed. But the inference is that mackerel, at least, and probably menhaden, do not feed during this time, as the fish appearing in the spring, which apparently could be only those of the previous season's production, are about the same size as when they left, and early adult mackerel are always lean. A similar condition seems to obtain to some extent among the menhaden, for often the early menhaden are very poor, according to the reports of the fishermen. It can hardly be imagined that the fish would refrain from eating for a long period if food were plentiful unless they to some extent hibernate. If they do not hibernate-become more or less dormant and inactive-it is hard to explain why they should resort to a foodless region when food abounds in other places.

In respect to the menhaden, not so much is known regarding its food as is known of the mackerel, but it has been shown to feed to some extent upon minute crustaceans, as do mackerel, and such food abounds in the winter months in the localities that both menhaden and mackerel have apparently left. The natural inference is then that temperature is the controlling factor. Both menhaden and mackerel endure a rather wide range of temperature and both linger late in the fall in northern littoral waters. Rather curiously, young menhaden seem to remain longer than adult fish and will stand reduction of temperature to a low degree. An experiment made by Mr. Vinal Edwards at Woods Hole, which will be described, supports the statement. The ultimate death of the fish may have been due to the sudden changes of conditions to which they were subjected rather than to the low degree of temperature alone.

On October $16 \mathrm{Mr}$. Edwards placed in the inner pool of the United States fisheries station about I barrel of young menhaden from 2 to 6 inches long. In three or four days they formed together in one school and continued so until December 21, when the temperature fell to $35^{\circ} \mathrm{F}$. The school then broke up and scattered about in the pool, some swimming near the surface, others near the bottom. When the sun was shining all would seek the sunny portions of the pool, avoiding the shade. On December 24 the temperature in the pool was $31.5^{\circ} \mathrm{F}$. and most of the menhaden swam near the surface but seemed otherwise undisturbed. On December 26 the temperature dropped to $30^{\circ}$ and the fish were less active, some swimming on their sides. On the night of Decemher $26-27$ it became much colder and snowed, and in the morning all of the fish were dead.

Thus it would seem that the disappearance of young and old in the late fall is to avoid extreme and sudden changes of temperature. They disappear, 
but where they go lias not been determined. Like all species whose winter quarters are unknown, the menhaden has been consigned by theory to the mysterious depths or contiguities of the Gulf Stream, a recrion ichthyologically lying beyond the "Pillars of Hercules." Warned by falling temperature, the fish is said to seek a stratum of congenial thermal conditions. All the known facts regarding this species indicate that it makes no extensive coastwise migrations, and since the requisite equable temperature, it is thought, can not be found anywhere else, the fish must find it in or near the Gulf Stream, notwithstanding the fact that so little is actually known about the winter conditions there. But why the fish should seek that locality for so brief a period has not been shown. Mackerel remain in northern waters until November and December and menhaden have been taken in quantities in sonthern Massachusetts in January, where they reappear in April.

Waters corresponding in temperature with those to which the fish have been accustomed in the summer or early fall could hardly be conducive to inactivity. Activity necessitates food. If the fish are sojourning in the midst of food and in an active condition, they would necessarily cat. Eating, they would continue fat. But mackerel and menhaden when first seen in the spring are as a rule very thin, indicating abstinence from food. If the fish live among an abundance of food, abstinence must be due to disinclination to eat. Such a condition could be ascribed to some degree of hibernation, but that would be inconsistent with warm waters. If, then, the fish is in such winter abode, it must be assumed that there is little or no food there. This, too, is contrary to the usual conditions. Food such as mackerel subsist on extensively, and menhaden to some degree in early spring, is particularly abundant in the spring, at least, in the Gulf Stream.and its neighborhood. Moreover, during the alleged fall migrations the lishes are not olserverl moving of shore Such movements as are observed are coastwise. After all, the fish are somewhere, but where is yet to be learned. Theory does not satisfy. As spring approaches inmense hodies of fish often appear swimming at or near the surface. This appearance of the fish has been ascribed to rising temperature and the breeding instinct. Surely the depthe of the Gulf Strcam or the equalile stratum have not become uncomfortably warm and forced them into the "cold wall " or arctic current? It is conceivable, however, if the fish were at or near the surface of the stream the warming water spread by southerly winds would cause the fish to advance with it. But these conditions are not invariable, and even if they were it would require some other impulse to force them into the much colder northern coastal waters. "Breeding instinct" fails to explain why immature fish are impelled to move in the same way as the adult breeders.

Let it be assumed that the fish-mackerel, menhaden, or other specieshave not gone in the winter " migrations " quite beyond the mysterious " pillars;" that they are lurking sonewhere along the coast, outside or within the bays, or 
both, according to the size of the fish; at a greater or less depth, and, if not dormant or hibernating, that they are more or less inactive and disinclined to rise to the surface, where the temperature and other conclitions are so variable and subject to sudden changes; that is to say, they are residing quietly at a depth of comparatively constant and uniform temperature, but of such degree that the fish are disinclined to activity, therefore requiring no food, but sub)sisting, as it were, upon the accumulated fat of the previous festal period. 'The revions, too, where, under this hypothesis, the fish reside are different for those of different sizes; in this instance, howerer, not on account of different feeding habits, but owing, perhaps, to the instinct of self-protection.

It is a well-known fact, as has been previously stated, that young or smallsized menhaden, up to 6 or 8 inches long, linger in the bays long after the larger ones have disappeared. It would therefore seen that the smaller fish are either less susceptible to the changes due to approaching winter, or that some other force predominates over their inclination to leave.

Granting, then, that the foregoing assumptions are true, when spring brings milder weather and less rigorous and sudden changes, the fish appear at the surface and their movements are again to some extent observable.

Regarding adult mackerel, it is known that these movements or so-called "migrations" precede the spawning process, but in immature fish-" "blinks," " spikes," "tinkers," etc., which have like movements-this can not be so. In menhaden as a whole it is not evident that the spring "migrations" are for spawning purposes. In the adult of both species the growing ova and milt doubtless warn the fish of the approaching "critical period," but this can not be the case with the immature fish. What, then, is the impelling force that causes the fish to come to the surface and move about in definite or indefinite directions? If the previously suggested hypothesis is still followed, it may be reasonably assumed that the fish, having consumed their accumulated fat, are impelled by their desire for food. If such is the case their movements will be in search of food and in the line of least resistance. Their subsequent movements also, except as controlled by the breeding instinct, whether at the surface or below, will be for food, although they may be directly and indirectly affected by the sane meteorological conditions, such as light, temperature, etc. When feeding the schools do not secm to move about very fast in any direction; therefore when in rapid motion they are probably in search of "pastures new." In support of this is the well-known fact that fish are seen going swiftly in directions exactly opposite to those that should be followed according to the "migratory" or breeding instinct. Such morements are usually, and sometimes correctly, ascriberl to cnemies heading them of and driving them in that direction. But if this were true in every case there slould be, and surely would be, some further eridenee of the enenies; for whenever the fish have been observed to be pursued by predaceous animals these animals are quite conspicuously manifest. 
The movements of both mackerel and merihaden when feeding, as mentioned before, are not rapid from place to place for any great distance, 1nt up and down, here and there, and around and around in that movement termed "cart-wheeling." While the latter movement is considered by many "just play," the manner of occurrence of minute organisms in aggregations of greater or less extent suggests that the fish are circling about in a school of these organisms, "scooping them in."

\section{SPAWNING MIGRATIONS OF THE MACKEREL.}

Regarding the migrations of fishes to their spawning places, every hnom fact in relation to menladen points to no extensive misration for the majority of the fish. Mackerel apparently travel greater distances, but there is no evidence in support of the former belief that they traverse the whole length of the coast from Hatteras to Labrador and the Gulf of St. Lawrence. It is hardly possible that one man would have sufficient endurance to observe day and night a body of fish for so long a period, and a change of watch would vitiate the evidence. While it is perhaps possible that a body of mackercl would remain at the surface continuously day and night, it is more than merly probable that it would oceasionally sink below the surface. If it dict, the observer could not be sure that the fish appearing subsequently were the same school.

Some years ago mackerel sighted by the seinirig fleet off Liverpool, Nova Scotia, were "followed" along the coast and around the eastern extremity of Cape Breton. The fish were up and down, sometimes a day or a nirht elapsing with no fish seen. It was noticed that while the schools of mackercl along the western portion of the Nova Scotia coast had alewives and shad mixed with them, those caught after rounding the castern end of Cape Breton had none of these adventitious fishes, but many schools were mixed with large herring, called by the fishermen "Newfoundland bloaters." Here, too, the mackerel were somewhat larger than those on the south shore.

Of course in the nature of things there is nothing to prevent the mackerel constituting the "body" from varying in size in different schools, each school perhaps haring different fish mixed with it. But it is hardly probable that had the alewives gone around Cape Breton, or the herring been at the south or west of that point, some would not lave been caught there. This gives rise to the suspicion that extensive migration is more apparent than real.

The condition of the reproductive organs of these fish, too, indicated that they were near the spawning time. According to the observer, each batch examined was thought to be within a week or so of it, which suggests that the fish may have been spawning along the coast. That those caught were not ripe ofiurs nu contra-argument. For it is possible that as the fish ripened they sank to some depth below the surface, where they spawned, and occasional few spent fish indicated that all did not reappear immediately afterwards. It is 
well known that some fishes linger on their spawning grounds long after they have spawned, and it is not impossible that mackerel remain near the place where the spawn is deposited for some time afterwards. The same may be said of menhaden. In support of this is the fact that sooner or later all adult menhaden clisappear from the Virginia shores and, temporarily at least, from the Carolina coast. There are not wanting fishermen, however, who aver that they catch menhaden along the Carolina shores at any time in suitable weather throughout the winter.

\section{SPAWNING OF MENHADEN.}

The time, place, manner, and duration of the spawning act of the menhaden are not known, and such meager data as are available on that subject are confusing. Direct observations by persons qualified to solve the problem have not been made, and the testimony of those who handle the greatest number of the fish is contradictory; individuals not infrequently change their views-sometimes even while being interviewed. Conjecture, however, is not eridence, and until thorough observations are made throughout the year the question can not be positively settled. But careful study of such data as are at land suggests that there is no one definite spawning season such as appears to be the case with mackerel, but that the conditions are analogous to those of the common herring, which spawns in some localitics in spring or early summer and in others in late fall or early winter, and perhaps more or less all summer. Some menhaden taken in Buzzards Bay throughout May and June up to July I 5 are well advanced, and a few ripe fish have been observed; but of the many examined few are found that are more than "well advanced," and it is unsatisfactory to try to estimate the length of time necessary to ripen the "well-advanced" fish. Out of 500 large menhaden taken at Sakonnet, R. I., on July 5, I892, 4 Io were females in various stages of development from very small to "nearly ripe." Of the 90 males, the majority contained milt "well advanced" and some were "ripe." From November 17 to 20 , during the same season, at North Truro, Cape Cod, large menhaden were found with ova and milt in various degrees of development, some males being "well advanced" and a few females "nearly mature."

From the last part of October to the first of December, 1894 , a large body of menhaden was observed to extend from Delaware Bay to Cape Lookout, "outside." These fish differed in appearance from the few taken within the bays at this time, being longer and their reproductive organs apparently very near maturity. V'ery many taken of Chesapeake Bay were examinerl, and the organs of those over 10.5 inches long always seemed to be in the same condition, which the observer could account for in no other way than that the fish were passing south toward warmer water to spawn. Subsequent observations off the 
coast of North Carolina in the vicinity of Beaufort, however, revealed hardly any appreciable change in the conditions of the reproductive organs.

It is the consensus of opinion among the fishermen of the Chesapeake that the "bay menhaden" spawn in February and March, and they present evidence to that effect. But they believe that the outside fish in late fall spawn at sea near the Gulf Stream or off the coast farther south.

In May, I9os, there was received at the United States National Museum a portion of a menhaden the length of which indicated that the whole fish was about 13 inches long. It contained undoubtedly nearly ripe roe. It was caught in the Chesapeake on the Sth of April and was brought in to Solomons, Calvert County, Md. This suggests, at least, that the opinions and statements of the fishermen regarding the spring spawning of menhaden in the Chesapeake may be correct.

The above-mentioned occurrence of large bodies of menladen outside, apparently near spawning condition, suggests also a fall or early winter spawning in that region, as do the data regarding the fish at North Truro. But the lack of knowledge regarding the length of time that would be required for the ova to mature prevents positive conclusions, for, instead of a few days or a week or two, a month or two or more might be necessary. The latter condition would bring the fish to maturity in February or March. In favor of the fall spawning, however, is the fact that a few undoubtedly recently spent fish were secured.

The evidence derived from young fish is unsatisfactory, since very little is known of their rate of growth. Young menhaden are seldom seen in the Woods Hole (Mass.) region before July, when they range from $I^{I} / 2$ to 3 inches in length, more often from $\mathrm{I}_{2}{ }_{2}$ to 2 inches. In November in the same locality they range from 2 to 5 inches in length, the majority being about 3 inches long, and all through the season there is another lot of immature fish, which, perhaps, average 8 inches in length.

In Chesapeake Bay young menhaden are said to appear in May, when they run from I ${ }_{2}^{1}$ to 2 inches in length. In March, I 894 , young menhaden from $t$ and 5 to 6 and 8 inches long were collected, and again in July from $\mathrm{I}^{\mathrm{I}}{ }_{2}^{\prime}$ to 5 inches. This indicates that there are two stocks of young fish - the earlier, perhaps, from the breed of the previous fall, and the later and smaller from that of the spring of the same year.

It has been suggested, because adult menhaden are seen far up bays and streams and the young are found still farther up, that the fish spawn in these localities; but there is nothing to indicate this. Fish, especially the young, run into shallow waters and often long distances up streams-even to the headwaters of small streams and creeks-probably, as has been previously stated, to escape enemies.

The most that can be said regarding the spawning places of menhaden is that nothing is positively known.

$$
\text { B. 13. I'. } 1908-19
$$




\section{RELATION OF MENHADEN TO FISHES THAT FEED UPON THEM.}

Goode says:

Among the enemies of menhaden may be counted every predaceous animal which swims in the same waters. Whales and dolphins follow the schools and consume them by the hogshead. Sharks of all kinds prey upon them largely; one hundred have been taken from the stomach of one shark. All large carnivorous fishes feed upon them. The tunny is the most destructive. ** * The pollock, the whiting, the striped bass, the cod, the squeteague, and the garfish are savage foes. The swordfish and the bavonet fish destroy many, rushing through the schools and striking right and left with their powerful swords. The bluefish and bonito are, however, the most destructive enemies, not even excepting man; these corsairs of the sea, not content with what they eat, which is of itself an enormous quantity, rush ravenously through the closely crowded schools, cutting and tearing the living fish as they go, and leaving in their wake the mangled fragments. Traces of their carnage remain for weeks in the great "slicks" of oil so commonly seen on smooth water in summer. **** I estimate the total number destroyed annually on our coast at a million million of millions; in comparison with which the quantities destroyed by men yearly sink into insignificance.

Such estimates, Goode states, are only approximate. It may be a question as to whether they are even approximate. If he deduces his estimates from a sufficient number of well-established facts, they may be considered approximate; but the evidence is that he reaches his conclusion by induction from a limited number of facts. One shark is known to have eaten roo menhaden. One sliark might contain I, ooo menhaden as a day's feast, but that would not be sufficient evidence upon which to base a conclusion that all sharks eat I, ooo menhaden each day in the year. One tumny may have been observed to almost annihilate a school of menhaden, but it does not follow that all the tunnies in the region consume a school of menhaden each every day. A school of bluefish is occasionally seen to wreak havoc upon hundreds of menhaden, but it does not sufficiently indicate that they do it every day. One squeteague having been found to devour nearly 50 menhaden does not clearly prove that the exclusive menu of the squeteague is nearly 50 menhaden a day. An average of 100 menhaden a day to a shark or its equivalent for three hundred days would require $333,3,3$, , $333,333,333$ sharks, or their equivalent in eating capacity, to devour a million million of millions menhaden in that length of time.

It is not a justifiable assumption that all of the predaceous animals previously enumerated feed exclusively and daily upon menhaden, even during the time that they are concurrently on the coast. Among fishes concerning whose habits we are better informed than those under discussion, it is known that they change their diet from time to time, and there are periods of days when they do not feed at all. One is almost as fully justified in assuming that a fish which is found to have eaten nothing during the day does not feed at all as that one found to contain a few menhaden feeds continuously and exclusively upon menhaden. I'et undoubtedly enormous quantities of menhaden are destroyed annually by fishes and other predaceous animals. Professor Goode further remarks that in estimating the importance of the menhaden to the United States it should be borne in 
mind that its absence from our waters would probably reduce all our other sea fisheries to at least one-fourth their present extent. If his premises are sound, the estimate is probably approximately correct, otherwise it is subject to criticism. In the Gulf of St. Lawrence, where, for a portion of the year at least, the principal food of the cod is capelin and herring, the absence of these foods is concomitant with the absence of cod.

In the second report of the Commissioner of Fisheries of the United States, Baird ascribes the decadence of the inshore cod fishery of New England to the enormous diminution in the number of alewives; "at least," he says, "the coincidence is remarkable." If the same relation is known to exist between the cod and the alewives on the New England coast as between the cod and herring or capelin in the Gulf of St. Lawrence, then such a conclusion is well founded. But as it is not shown to be a fact, it can be considered only a conjecture. Surmises based on coincidences will not solve problems. Therefore, in order to determine even with any degree of approximation the effects of the reduction in numbers of any species in our waters upon other species to any extent feeding upon them, the habits of not only these forms but others as well must be very thoroughly known in all their intricate interrelations.

The list of fishes enumerated by Goode as destructive enemies of menhaden does not comprise all the species that at times eat menhaden, and it includes some that are not known to feed upon them at all. The assumption that they do is made partly from the fact that they are built on the model of predaceous fishes, and partly because they are sometimes caught on menhaden bait. The first part is to some extent justified, since it is safe to assume that a species which to any extent eats other fishes will cat menhaden if it can yet them; but it is not safe to infer that it consumes enormous quantities, as its habits may be such that it is not brought in contact with such numbers, or food which it prefers may be at the same time present. That a fish is caught on certain kinds of bait or that the bait is the most successful to use does not signify that the principal food of the fish is the species used as bait. Tot infrequently the best bait for some fishes is something that does not coinhahit those waters.

To what extent any species subsists upon menhaden and the number of species that feeds to some extent upon them is not known. Therefore no reliable deductions can be made regarding the effect upon such fishes were they deprived of the supply of menhaden. However, every menhaden caught reduces the number of those fish by one; every thousand or million reduces the number by a thousand or a million. Therefore the menhaden fisheries must, theoretically at least, have their effect upon the species that feed upon the menhaden by depriving them of so much food. They also have effect upon the menhaden sought by rendering those that escape capture more liable to be eaten by predaceous enemies. 
Whether the effects of fishing are of appreciable injury to the fish depends upon the time, place, and amount of fishing, as well as upon the liabits of the fish and the number caught. If the fish have a limited spawning ground to which they resort every year-for instance, a small bay, estuary, or mouth of a stream-constant fishing with purse seines and obstructive pounds and traps must necessarily seriously affect the number of fish reaching the spawning ground, consequently the number produced that season. And if such fishing is carried on at or near every spawning place of the species, as well as at a distance from it, the injurious effects would obviously be still greater, and in time would result in a diminished number of the species. If the species is greatly reduced in numbers, then the food supply of the fishes depending upon this particular species for subsistence is correspondingly reduced. The consequence of this would be that this species would be reduced by starvation or would be forced to depend upon other species for food. The latter is the most natural effect, and this in turn would deprive still other species of their food or reduce their numbers either as adults or young, or both. Other species being deprived of their food would repeat the process, and thus it would go on until nothing remained.

While such a condition is theoretically conceivable, it is not so in fact, except to the extent that if for any reason the food of a species is withdrawn the species disappears, doubtless in search of food elsewhere, and when its principal food is abundant the fish feeding upon it would naturally be plentiful. Exceptions that might be cited may be only apparent, for, as has been previously suggested, probably no fish feeds exclusively upon any one thing or depends upon any one species. The shark, tunny, or bluefish would hardly be likely to distinguish schools of menhaden from schools of other silvery fishes like the alewives, which sometimes equally abound with the menhaden along the coast. Thus the absence of bluefish from any section when menhaden are present or the presence of bluefish when menhaden are absent in each instance is due to the same thing-the presence of satisfactory food in one place or the other. There is no doubt that the bluefish disastrously pursues menhaden, but it is known to pursue other species with equal disaster.

The effects of the complete extermination of menhaden from the seas may be inferred from the effects of local disappearances for a term of years and where there is no evidence that the fishes that fed upon them there suffered in consequence of their departure. It may with propriety be stated here that such "unaccountable" disappearances took place long before modern fish traps and purse seines were known. Subsequent like disappearances and reappearances, again disappearances without reappearances, can not, then, logically be laid to the purse seines and steamers. But there can be no doubt in the minds of those who have observed the operations of menhaden and mackerel purse seines that there is at least a temporary more or less modifying 
effect upon the movements of the schools of fish. It may still, however, be an open question whether the mackerel have not always been fully as intelligent as they now seem to be when they evade the nets so successfully that the fishermen call them "educated fish."

\section{CONCLUSION.}

In this paper there has been no attempt to explain the mysterious phenomena exhibited by the fishes discussed, but merely to suggest lines of investigation that might be worth making. There have been frequent more or less critical references to the contributions of Baird and Goode, but with no wish to attempt to controvert any of their sound arguments. The theories advanced by them are as logical and sound as the evidence upon which they were based would permit, since the conclusions were reached by assembling and sifting the testimony of unscientific observers. Such evidence is difficult to collate satisfactorily, owing to the more than frequently contradictory character of even that obtained from intelligent, observant, and equally honest persons. The views of the purse seiner may be quite contrary to those of the gill netter, trap, or pound fisherman, yet each probably is honestly convinced of the correctness of his views.

It is needless to say that in this paper few, if any, new facts have been added to the knowledgre of the fishes to which it refers. But its object will be attained if, by indicating possible errors in the theories previously held, it causes a realization of the prevalent profound ignorance regarding the greater part of the life of many of our common and commercially important fishes and almost total lack of knowledge of the habits and life history of the menhaden, and thus proves instrumental in instigating the much needed thorough, systematic investigations of those subjects. 






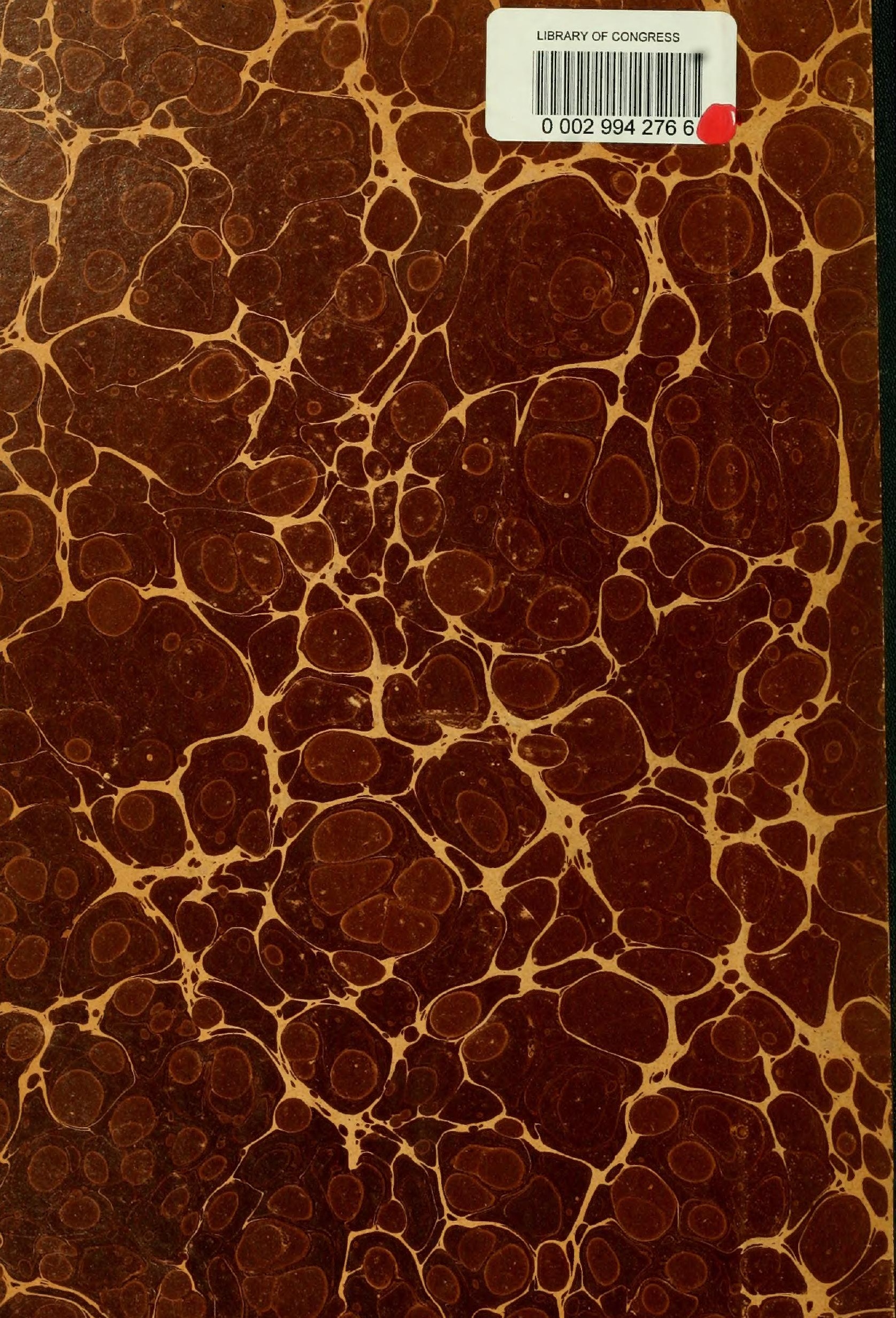

